\section{The ethics of cosmetics}

\author{
Stephen Hancocks OBE \\ Editor-in-Chief
}

Send your comments to the

Editor-in-Chief,

British Dental Journal

64 Wimpole Street,

London

W1G 8YS

Email bdj@bda.org
When I was a teenager our family dentist, and a man who positively influenced me in my choice of dentistry as a career, was, how might one say politely? not entirely conventional in his manner. Some, many, patients loved his no-nonsense approach to what was then a traditionally rather stuffy profession. Others, some detractors, scornful of what they saw as a less respectful approach, arrived once and never returned. He was, as one may have ruefully described, a 'one off'.

Yet despite, or perhaps because of this he did speak some remarkably good sense. 'How long will it last?' asked patients of a new restoration or a proposed appliance. 'Look,' the riposte came with an air of casual philosophy crossed with an exasperation borne of years of tedious experience in such affairs, 'the good Lord made me and I am not going to last for ever so don't expect anything I do to be better than that.' Ho hum. Not exactly our client-friendly, politically correct new millennium approach and yet there remains an enviable rock of common sense there. All that we do in dentistry is only as good as the combination of our individual skills and the patient's subsequent home care can make it; everything put together soon or later falls apart. Conversely, the less we do, the less likely there is to be a disappointment, a scene, a failure of expectation, the threat of litigation, the need for further intervention and most crucially the lack of impetus for more dentistry.

\section{ENAMEL SACRIFICED ON THE ALTAR OF VANITY}

Minimal intervention has become a buzz-phrase of recent years and nowhere more so than in cosmetic, or aesthetic dentistry. I could spend the whole page, dozens of pages, a book discussing the difference between the two. Commercial television versus the BBC perhaps, fish, chips and mushy peas as rivals to sea bass, French fries and jus of petite pois, the comparisons are almost endless and you will have your own favourites. The recent conference of the British Academy of Cosmetic Dentistry (BACD) provided the opportunity to revisit the debate which has started to re-emerge in relation to the ethics of removing, or as some would term destroying good hard tissue in the name 'only' of looks, be they described as cosmetic or aesthetic. BACD members, in a creditable attempt to meet the critics head-on, used the conference to discuss the relative merits of improving appearances, specifically smiles, by technical means in the least interventive ways possible, defending the fact that actually people, patients, do attend with one of their objectives being the attainment of a better smile, whiter teeth and an improved self-image.
The hecklers scorn the acres of enamel being air-rotored into irrigated oblivion, sacrificed on the altar of vanity, and for what? Questionable motives, low ethics and maximum profit? Yet conceived for the right reasons and provided ethically and with all the appropriate skill that a good clinician can muster, the replacement of the minimal amount of calcified tissue with a material which looks and functions as well as any non-natural material can, is the central activity of dentistry. It applies to everything we do and yet how much less frequently does the question arise over the veracity of a posterior composite, or an amalgam for that matter?

The 'daughter test' (or more controversially, and a term apparently rejected by an American dental journal as too controversial, the 'lover test') is often wheeled to the fore; played like a trump card in the macho game of who can out-moralise the other. It runs along the lines of "would you allow someone to do to your own daughter that which you are proposing to do to your patient?' The fancy footwork here involves almost as much of a distraction technique as the alleged salesmanship in palming off supposedly dodgy crowns and veneers. We all immediately imagine not our own daughters at all (even those who have them) but some beautiful young bride advancing up the aisle with the perfect Hollywood gleam that none of us would dream of waving a diamond bur anywhere near. We never pause to visualise a middle-aged daughter (yes, they do grow up) with chipped and stained enamel for whom an ethically chosen, consented to and well executed treatment plan might make the difference between low self-esteem and finding a new partner - would you let your son marry such a woman? You see, you're assuming again that he is a 'toy boy' whereas in fact he is middle-aged too. To the pure all things are pure.

Yes, it is certainly possible to argue that there are unscrupulous members of the profession, as unfortunately there are in any profession, who will misdirect their patients for reasons of personal gain and with scant regards to the biological consequences of their actions. It is however equally possible to argue that with the application of good ethics, clinical skills and collaborative patient involvement, cosmetic as well as all other dentistry is a perfectly acceptable endeavour.

How long might a well reasoned editorial last? I suppose until we find stems cells capable of re-growing dental enamel. So don't expect this to be maintained forever either.

DOI: $10.1038 /$ sj.bdj.2011.1004 